\title{
PENINGKATAN HASIL BELAJAR MATEMATIKA SISWA KELAS VIII SMPN 13 MATARAM TAHUN AJARAN 2017/2018 MELALUI LESSON STUDY
}

\author{
Baidowi $^{1}$, Nurul Hikmah ${ }^{2}$ dan Amrullah ${ }^{3}$ \\ ${ }^{1}$ Program Studi Pendidikan Matematika FKIP Universitas Mataram Jalan \\ Majapahit No.62 Mataram Email :baidowiunram@gmail.com. \\ ${ }^{2}$ Program Studi Pendidikan Matematika FKIP Universitas Mataram Jalan \\ Majapahit No. 62 Mataram Email :nuru123483@yahoo.co.id \\ ${ }^{3}$ Program Studi Pendidikan Matematika FKIP Universitas Mataram Jalan \\ Majapahit No.62 Mataram Email :amrullah.mtk@gmail.com
}

\begin{abstract}
Abstrak.Penelitian bertujuan meningkatkan hasil belajar siswa Kelas VIII SMPN 13 Mataram Tahun Ajaran 2017/2018 dan mengetahui tanggapan siswa terhadap implementasi pembelajaran berbasis lesson study. Penelitian dilakukan dengan tahapan-tahapan yang berlaku dalam pembelajaran berbasis lesson study. Pelaksanaannya berlangsung 3 siklus disesuaikan dengan alokasi waktu dan materi pokok bahasan yang dipilih. Tiap siklus terdiri dari plan, do dan see. Lokasi penelitian di SMPN 13 Mataram, pelaksanaan Juli - November 2017. Subyekpenelitian Siswa Kelas VIII SMPN 13 Mataram. Pegumpulan data dengan teknik dokumentasi, observasi, dan tes. Instrumen meliputi : lembar observasi, tes hasil belajar. Data hasil observasi dianalisis secara deskriptif untuk mengetahui kualitas proses belajar mengajar dan kemajuan hasil belajar. Sedang peningkatan penguasaan konsep dan psikomotorik dilakukan dengan membandingkan pencapaian skor individu maupun kelompok dari hasil tes.Hasil penelitian menunjukkan kemajuan hasil belajar siswa Kelas VIII SMPN 13 Mataram
\end{abstract}

Kata Kunci :Hasil Belajar, Matematika, Lesson Study

\section{PENDAHULUAN}

Matematika merupakan salah satu ilmu pengetahuan yang menjadikan manusia mampu berpikir logis, rasional dan percaya diri, disamping sebagai salah satu alat bantu dalam menyelesaikan permasalahan-permasalahan nyata yang dapat disederhanakan dalam model matematika. Oleh karena itu agar diperoleh hasil yang optimal dalam pembelajaran matematika diperlukan implementasi model, strategi, pendekatan ataupun metode yang tepat, sesuai dengan karateristik materi maupun peserta didik. 


\section{MANDALIKA}

Mathematics and Educations Journal

Volume 1 Nomor 1, Juni 2019

Dalam rangka meningkatkan mutu pendidikan, sistem pendidikan nasional selalu mengalami perubahan-perubahan sesuai dengan tuntutan dan harapan masyarakat.Pengembangan kurikulum setiap jenis dan jenjang pendidikan disesuaikan dengan tahap perkembangan siswa dan kesesuaian lingkungan, kebutuhan pembangunan nasional dan perkembangan IPTEK.Untuk menetukan bahwa pendidikan bermutu atau tidak, dapat terlihat dari indikator-indikator mutu pendidikan. Salah satunya dapat terlihat dari keberhasilan dan meningkatnya aktivitas siswa dalam proses pembelajaran.

Keberhasilan proses pembelajaran tidak terlepas dari kemampuan guru untuk menerapkan model-model pembelajaran yang berorientasi pada peningkatan intensitas keterlibatan siswa secara efektif dalam proses pembelajaran. Penerapan model pembelajaran yang tepat pada dasarnya bertujuan untuk menciptakan kondisi pembelajaran yang memungkinkan siswa dapat belajar secara aktif dan menyenangkan sehingga siswa dapat meraih prestasi belajar yang optimal.Akan tetapi model pembelajaran yang dilaksanakan oleh guru pada umumnya, terutama dalam pembelajaran matematika tidak variatif tanpa melihat kondisi siswa dan karakteristik materi yang diajarkan sehingga berdampak pada rendahnya prestasi belajar yang diperoleh siswa.Padahal matematika merupakan salah satu bidang ilmu yang berperan cukup penting dari sekian banyak bidang ilmu yang ada dan selalu mendapat prioritas untuk dikembangkan, karena matematika merupakan sarana untuk memecahkan masalah dalam kehidupan sehari-hari. Namun jika kita melihat fenomena yang ada, khususnya di SMP Negeri 13 Mataram, keberhasilan belajar matematika masih rendah.

Rendahnya pembelajaran ini, salah satunya dijumpai di kelas VIII-A SMP Negeri 13 Mataram.Berdasarkan observasi di sekolah tersebut, diperoleh informasi dari guru SMP Negeri 13 Mataram bahwa prestasi belajar matematika siswa masih rendah.Hal ini terlihat dari ketuntasan belajar klasikal masing-masing kelas VIII belum ada yang memenuhi kriteria keberhasilan pembelajaran yang ditetapkan oleh SMP Negeri 13 Mataram yaitu $\geq 85 \%$ dari siswa di suatu kelas tuntas belajar dan ketuntasan belajar klasikal kelas dimana KKM yang ditetapkan di SMP Negeri 13 Mataram adalah nilai 75. 


\section{MANDALIKA}

Mathematics and Educations Journal

Volume 1 Nomor 1, Juni 2019

Berdasarkan observasi awal yang dilakukan di kelas VIII SMP Negeri 13 Mataram, diperoleh beberapa permasalahan dalam pembelajaran, antara lain Guru lebih sering menyajikan pembelajaran dengan menyampaikan materi pembelajaran secara langsung sehingga tampak sebagai sebuah aliran informasi dari guru ke siswa kemudian diikuti pemberian contoh soal dan diakhiri dengan pemberian tugas untuk menguji pemahaman siswa. Cara mengajar seperti ini serupa dengan metode ceramah di mana metode ini cenderung diarahkan pada aliran informasi dari guru ke siswa.Siswa dipandang sebagai individu pasif yang tugasnya hanya mendengarkan, mencatat, dan menghafal (Sanjaya, 2011).Hal ini menyebabkan kurangnya kemampuan siswa dalam menyelesaikan persoalan-persoalan matematika dan kurangnya interaksi yang terjadi antara guru dan siswa yang terlihat hanya sebagian kecil saja dari siswa yang berani mengajukan pertanyaan dikarenakan siswa lebih berani bertanya kepada teman sebangku daripada mengajukan pertanyaan ke guru.

Guru yang profesional diharapkan mampu melaksanakan pembelajaran yang aktif. Inovatif, kreatif, enak dan menyenangkan (PAIKEM). Untuk mewujudkannya guru harus mampu memilih dan memetakan model pembelajaran yang sesuai dengan karakteristik kompetensi dasar dan indikator dalam mata pelajaran tersebut. Dengan memilih dan memetakan model pembelajaran yang sesuai maka pembelajaran akan efektif.

Keberadaan guru sangatlah urgen dalam proses pembelajaran, karena guru yang menentukan, apakah tujuan pembelajaran tercapai atau tidak?, bagaimana kompetensi peserta didik? Proses pembelajaran merupakan upaya yang dilakukan guru untuk mencapai tujuan yang dirumuskan dalam kompetensi dasar. Namun realita di lapangan menyebutkan bahwa masih banyak kendala dalam pembelajaran.

Mencermati hal tersebut di atas, perlu adanya perubahan dan pembaharuan, inovasi ataupun gerakan perubahan mind set kearah pencapaian tujuan pendidikan pada umumnya dan khususnya tujuan pembelajaran. Pembelajaran matematika hendaknya lebih bervariasi metode maupun strateginya guna mengoptimalkan potensi peserta didik. Upaya-upaya guru dalam mengatur dan memberdayakan berbagai variabel pembelajaran, merupakan bagian penting dalam keberhasilan peserta didik mencapai tujuan yang direncanakan. Karena itu pemilihan metode, strategi dan pendekatan 


\section{MANDALIKA}

Mathematics and Educations Journal

Volume 1 Nomor 1, Juni 2019

dalam mendesain model pembelajaran yang berguna dalam mencapai iklim PAIKEM ( Pembelajaran Aktif, Inovatif, Kreatif, Efektif, Menyenangkan ) adalah tuntutan yang harus diupayakan oleh guru.

Selain model pembelajaran yang perlu menjadi acuan pembelajaran, konsep lesson study perlu dikombinasikan dengan model pembelajaran sebagai pendukung dalam pembelajaran. Lesson Study muncul sebagai salah satu alternatif guna mengatasi masalah praktik pembelajaran yang selama ini dipandang kurang efektif. Menurut Slamet Mulyana, (2007;20) Lesson Study sebagai salah satu model pembinaan profesi pendidik melalui pengkajian pembelajaran secara kolaboratif dan berkelanjutan berlandaskan pada prinsip-psrinsip kolegalitas dan mutual learning untuk membangun komunitas belajar.

Lesson study merupakan salah satu upaya pembinaan untuk meningkatkan proses pembelajaran yang dilakukan oleh sekelompok guru secara kolaboratif dan berkesinambungan, dalam merencanakan, melaksanakan, mengobservasi dan melaporkan hasil pembelajaran, yang dapat mendorong terbentuknya sebuah komunitas belajar (learning society) yang secara konsisten dan sistematis melakukan perbaikan diri, baik pada tataran individual maupun manajerial.

Untuk mengatasi permasalahan di atas adalah dengan cara melakukan inovasi pembelajaran dengan menerapkan model pembelajaran yang lebih efektif untuk pengajaran matematika. Model pembelajaran merupakan salah satu faktor yang menentukan keberhasilan suatu program pembelajaran.Pembelajaran yang dilakukan di SMP Negeri 13 Mataram saat ini sebagian masih menggunakan metode konvensional (metode ceramah).Metode pembelajaran yang kurang bervariasi menyebabkan siswa merasa bosan belajar.Pada umumnya guru masih menggunakan metode ceramah, membahas LKS, dan Tanya jawab, yang mana dalam Tanya jawab tersebut hanya siswa tertentu saja yang mau bertanya dan menjawab pertanyaan, sehingga pembelajaran kurang bervariasi.Menurut peneliti hal tersebut menyebabkan siswa merasa bosan dan cenderung ramai sendiri bersama teman sebangkunya.Salah satu model pembelajaran yang dapat digunakan untuk memenuhi kebutuhan tersebut adalah dengan menerapkan model pembelajaran kooperatif. 
Mathematics and Educations Journal

Volume 1 Nomor 1, Juni 2019

\section{METODE PENELITIAN}

\section{A. Pendekatan Penelitian}

Pendekatan penelitian ini adalah penelitian tindakan dengan model lesson study.Penelitian ini bertujuan meningkatkan hasil pembelajaran matematika melalui penerapan model pembelajaran dan lesson study siswa kelas VIII SMP Negeri 13 Mataram tahun ajaran 2017/2018.

\section{B. Prosedur Penelitian}

Penelitian ini menggunakan model lesson study yang dikembangkan oleh Lewis (2002) dengan langkah-langkah sebagai berikut:

1. Persiapan

Kegiatan yang dilakukan pada tahap ini adalah (1) peneliti meminta teman sejawat dan guru untuk menjadi kolaborator dan narasumber, (2) bersamasama peneliti menentukan fokus penelitian lesson study pada mata pelajaran Matematika berdasarkan analisis kebutuhan, (3) mempersiapkan RPP, (4) mempersiapkan materi, (5) membuat pedoman observasi.

2. Rencana Pembelajaran

Rencana pembelajaran yang disepakati dan yang dilakukan adalah, (1) penelitian dilakukan mulai dari pertemuan ke-9 sampai dengan 15, dari tanggal 19September sampai dengan 22Noveember 2017, dengan demikian sebanyak 7 tatap muka.Pembelajaran bertujuan menanamkan kemandirian dan meningkatkan kemampuan dan keterampilan pada diri siswa melalui tugas individu.

3. Implementasi Tindakan

a. Perencanaan (Plan)

Pada kegiatan ini, guru mata pelajaran Matematika dan tim peneliti mendiskusikan tentang materi pokok yang tertuang dalam Rencana Pelaksanaan Pembelajaran (RPP) yang telah dibuat oleh guru Matematika. Materi-materi yang penting untuk pembelajaran terkait fokus penelitian adalah: skenario pembelajaran, indikator, LKS, Media, dan model pembelajaran, kisi-kisi soal tes.

b. Implementasi Pembelajaran (Do) 
Pada kegiatan ini, guru melaksanakan skenario pembelajaran dari pendahuluan, kegiatan inti sampai pada menutup pembelajaran. Observer mengamati proses pembelajaran dan mencatat hal-hal penting yang terjadi di kelas. Observasi lebih difokuskan pada respon dan aktivitas siswa di kelas.

c. Observasi (See)

Kegiatan observasi dilakukan oleh dosen, dan dipandu oleh lembar observasi. Observasi diarahkan pada motivasi balajar siswa di ruang kelas, teknik pengelolaan kelas, caraguru mengefektifkan pencapaian tujuan, pemanfaatan media yang ada, dan cara guru memotivasi siswa.

d. Refleksi

Kegiatan refleksi melibatkan peneliti sebagai guru pengampu mata pelajaran Matematika, observer, dan seorang tim peneliti (sebagai moderator). Dalam hal ini guru pengampu mata pelajaran Matematika mengungkapkan kesan terhadap pembelajaran yang dilakukannya, dan respon siswa. Adapun observer memberikan masukan berdasarkan data yg diperoleh, demi kebaikan pembelajaran selanjutnya.

\section{Teknik Pengumpulan Data}

Teknik pengumpulan data pada penelitian ini adalah observasi, angket, dan kumpulan tugas siswa dan fotosiswa saat di kelas.

\section{Observasi}

Kegiatan observasi dilaksanakan pada saat proses pembelajaran berlangsung, dan dipandu dengan lembar observasi. Observer mencatat secara cermat respon dan aktivitas siswa selama pembelajaran di kelas. Observasi diarahkan pada motivasi belajar mahasiswa, situasi kelas, teknik pengelolaan kelas, caraguru mengaktifkan siswa dan pemanfaatan media, cara guru memotivasi siswa.

2. Angket

Terdapat dua angket dalam penelitian ini.Angket I berupa pertanyaan-pertanyaan tertulis yang memerlukan jawaban tertulis.Angket II berupa pertanyaan yang dilengkapi jawaban pilihan dan pertanyaan yang dijawab secara bebas (angket terbuka). 


\section{MANDALIKA}

Mathematics and Educations Journal

Volume 1 Nomor 1, Juni 2019

\section{Teknik Analisis Data}

Data yang diperoleh dalam penelitian ini dianalisis secara kualitatif.Analisis data dilakukan menurut karakteristik masing-masing.Data diklasifikasi dan dikategorisasi secara sistematik dan menurut karakteristiknya.

\section{E. Teknik Keabsahan Data, Analisis, dan Hasil Penelitian}

Cara mengimplementasikan lesson study, khususnya dalam pengumpulan data analisis, dan menyimpulkan hasil penelitian ditriangulasikan untuk keperluan keabsahan cara penelitian, data, dan hasil penelitian. Triangulasi dilakukan dengan cara berdiskusi, meminta pendapat dan justifikasi dari teman sejawat yang berpengalaman di bidang penelitian tindakan.

\section{F. Indikator Keberhasilan}

Indikator keberhasilan dari penelitian ini adalah tercapainya hasil belajar yang memenuhi ketentuan hasil belajar siswa mengalami peningkatan tiap tahapnya dan terjadi peningkatan persentase ketuntasan dalam setiap tahap yang memenuhi KKM $75 \%$.

\section{HASIL DAN PEMBAHASAN}

Penelitian ini dilaksanakan dalam 3 siklus dengan subyek penelitiannya adalah siswa kelas VIII A semester ganjil tahun ajaran 2107/2018.Dimulai pada bulan Oktober sampai November 2017 di SMPN 13 Mataram tahun ajaran 2107/2018 di kelas VIIIa. Adapun yang menjadi Guru Model adalah Aminah Endang Astuti, S.Pd. dan yang bertindak sebagai observer antara lain: Baidowi, M.Si, Dr. Amrullah dan Nurul Hikmah, M.Sc. dan salah satu guru Matematika SMPN 13, yaitu Slamet Nugroho, S.Pd.

Adapun materi yang dijadikan topik dalam penelitian ini adalah berturut turut padas iklus 1, 2 dan 3 adalah Menggambar Grafik Fungsi dan Teorema Pythagoras.

Adapun pelaksanaan Lesson Studi dapat dipaparkan sebagai berikut:

1. Siklus 1 
Kegiatan pembelajaran pada siklus 1 dilaksanakan 1 kali pertemuan, pada tanggal 3 Oktober 2017 dengan materi Menggambar Grafik Fungsi. Kegiatan dalam Siklus 1 terdiri dari :

a. Perencanaan

Kegiatan plan Lesson Studi berlangsung pada hari kamis 28 Oktober 2017 di Perpustakaan SMPN 13 Mataram. Pada saat tahap plan Lesson dihadiri oleh 2 orang guru Matematika SMPN 13 Mataram dan 3 orang dosen yang dipimpin oleh Baidowi, M.Si. Materi yang akan didiskusikan adalah tentang Menggambar Grafik Fungsi di Kelas VIII A. Pada tahapan ini didiskusikan beberapamhal terkait pemilihan metode pembelajaran dan model pembelajaran dimana dalam model yang kaan diimplementasikan diharpakan siswa mampu bekerja sama dengan anggota kelompoknya dan tidak bergantung pada temannya yang pintar saja sebagaimana selama ini jika diterapkan metode didskusi siswa cenderung bergantung ke temannya yang pintar. Penyempurnaan Lembar Kerja Siswa (LKS) agar sesuai dengan tahapan yang diharapakan terkait dengan masih lemahnya siswa dalam masalah berhitung sehingga LKS diharapkan dapat memfasilitasi siswa dalam memahami materi dengan lebih baik dan memberikan kesempatan kepada siswa agar lebih bertanggung jawab melaksanakan tugas yang diberikan. Selanjutmya didiskusikan juga penyempurnaan Media, Rencana Pelaksanaan Pembelajaran, dan lembar obsevarvasi.

Pada tahap Perencanaan telah dihasilkan perangkat pembelajaran dan pendukung kegiatan penelitian yang meliputi :

1). Rencana Pelaksanaan Pembelajaran Siklus 1.

2). Lembar Kerja Siswa Siklus 1.

3). Lembar Aktivitas Guru dan siswa Siklus 1.

4). Soal Evaluasi Siklus 1dalam bentuk essay.

5). Pedoman penskoran Evaluasi Siklus 1.

6). Kelompok Siswa yang heterogen beranggotakan 5 orang siswa.

b. Pelaksanaan Tindakan 
Dalam pelaksanaan tindakan yang merupakan implementasi dari model pembelajaran kooperatif yang telah direncanakan dalam RPP sehingga secara garis besar langkah-langkah yang dilakukan dalam Siklus 1 ini adalah :

\section{1) Pendahuluan}

Pada tahap ini Guru mengecek kesiapan siswa dengan mengabsensi siswa dan meminta siswa menyiapkan segala sesuatu yang terkait dengan pembelajaran, selanjutnya Siswa mendengarkan tujuan pembelajaran yang akan dicapai, kemudian guru memberikan apersepsi dan motivasi dengan melakukan tanya jawab untuk menggali pengetahuan awal siswa yang berkaitan dengan materi yang akan dipelajari.

\section{2). Kegiatan Inti}

Dalam Tahap ini setelah siswa diorganisasikan siswa dalam beberapa kelompok belajar heterogen, selanjutnya Membagikan LKS kepada setiap siswa. Meminta setiap siswa mengerjakan LKS yang dibagikan dengan berdiskusi bersama kelompoknya. Beberapa perwakilan kelompok menjelaskan hasil diskusinya di depan kelas dan guru meminta kelompok yang lain untuk menanggapi jawaban kelompok yang presentasi Guru memberikan penguatan terkait hasil presentasi dan diskusi siswa.

3). Penutup

Membimbing Siswa dalam menyimpulkan materi yang sudah dibahas dan Memberikan penekanan pada hal-hal penting yang perlu diklarifikasi kembali. Terakhir guru Menyampaikan materi yang akan dipelajari pada pertemuan selanjutnya.

c. See

Berdasarkan gambaran di atas dapat diperoleh beberapa kelemahan dalam siklus 1 ini, antara lain:

1. Beberapa siswa tidak bisa mengikuti pelajaran dengan baik.

2. Ada siswa yang tidak mengerti dengan instruksi yang disampaikan guru model

3. Pada saat penyampaian materi, beberapa siswa berbicara dengan temanya sebangkunya 
4. Sebaiknya guru model jangan lupa menyampaikan materi prasyarat. Ini penting agar kegiatan inti dapat berjalan seperti yang diharapkan.

5. Guru model sebaiknya menjelaskan secara singkat tentang cara mengisi atau mengerjakan LKPD secara berkelompok agar kerja kelompok menjadi lebih antusias dan tidak ada siswa yang pasif.

6. Sebaiknya guru model cepat meralat kesalahan ketik di LKS

7. Pada kegiatan presentasi, sebaiknya guru model mengkondisikan seluruh siswa siap tampil, siap untuk memperhatikan, mendengarkan, dan menanggapi serta menjawab pertanyaan yang muncul

Dengan adanya pengalaman belajar dalam menemukan konsep sendiri, diharapkan bisa melekat lebih lama dalam memori siswa untuk jangka yang lebih panjang dan akibatnya tentunya siswa memiliki hasil belajar yang lebih baik. Hal ini senada dengan yang ungkapkan Turmudi (2011 : 71), dalam proses pembelajaran guru memberikan permasalahan dan memberi kesempatan siswa untuk menemukan sendiri penyelesaiannya, sehingga siswa secara aktif mengkonstruksi sendiri pengetahuan matematikanya dan proses belajar akan bermakna bagi siswa.

Berdasarkan hasil penelitian, terdapat beberapa kelebihan dan kelemahan dari Lesson Studi . Kelebihannya antara lain :

a) Siswa aktif dalam kegiatan pembelajaran dan penyelesaian LKS

b) Siswa dapat memahami materi yang dipelajari dengan baik

c) Siswa mampu mengaplikasikan materi dengan permasalahan sehari-hari dengan baik.

d) Guru lebih faham tentang bagaimana membuat perangkat pembelajaran yang sesuai dengan karakteristik siswa dan karakteristik materi.

Sedangkan kelemahannya, antara lain:

a) Pembelajaran yang umumnya menggunakan diskusi kelompok menghabiskan waktu yang lebih banyak, sehingga perlu manajemen waktu yang sangat baik.

b) Jika digunakan secara terus menerus dikhawatirkan akan menimbulkan kejenuhan bagi siswa 


\section{MANDALIKA}

Mathematics and Educations Journal

Volume 1 Nomor 1, Juni 2019

Adapun terkait implementasi dari model pembelajaran dikleas, sebelum di terapkan alangkah baiknya mempertimbangkan beberapa hal berikut ini:

a) Mengkondisikan siswa baik secara psikis maupun mental untuk siap belajar sebelum memulai pembelajaran

b) Menciptakan suasana pembelajaran yang rileks sehingga siswa mampu mengutarakan pendapat maupun pertanyaan tanpa merasa takut dan malu.

c) Memastikan materi prasyarat terkait materi yang akan dipelajari sudah dikuasai dengan baik oleh siswa, sehingga pembelajaran bisa optimal dan manajemen waktu menjadi lebih efektif dan efisien.

\section{SIMPULAN DAN SARAN}

\section{A. SIMPULAN}

Berdasarkan hasil penelitian dan pembahasan yang telah diuraikan di atas, dapat ditarik kesimpulan sebagai berikut: Penerapan Model Pembelajaran dan Lesson Studi dapat meningkatkan hasil belajar matematika siswa kelas VIII SMP Negeri 13 Mataram tahun ajaran 2017/2018.

\section{B. SARAN}

1. Kegiatan Lesson Study sebaiknya dilakukan pada pokok-pokok bahasan yang dianggap sulit oleh siswa.

2. Dengan adanya kegiatan Lesson Study ini diharapkan guru dan teman sejawatnya bisa membangun kerja sama yang baik terutama saling memberikan masukan yang positif agar bisa memperbaiki proses pembelajaran yang lebih maksimal, dan dapat mengembangkan inovasiinovasi baru dalam proses pembelajaran selanjutnya.

\section{DAFTAR PUSTAKA}

[1] Aryulina, D. (2010). Penerapan Lesson Study pada Microteaching bagi Calon Guru Biologi. Forum Kependidikan, Vol. 30, Nomor 1: 14-19.

[2] Fernandez, M. L. (2005). Exploring "Lesson Study" in Teacher Preparation. Dalam Chick, H. L. \& Vincent, J. L. (Eds.): Proceedings of the 29th Conference of the International Group for the Psychology of Mathematics Education, 2: 305-312. Melbourne: PME. (Online). (http:////www.emis.de/proceedings/PME29/P, diakses 20 Pebruari 2015). 


\section{MANDALIKA}

Mathematics and Educations Journal

Volume 1 Nomor 1, Juni 2019

[3] Hartanti, P. (2007). Penerapan Lesson Study dalam Pembelajaran Statistika Sebagai Upaya Meningkatkan Hasil Belajar Siswa Kelas 3 Akuntansi 1 SMK Negeri 1 Jember. Makalah disajikan dalam KGI 2007, Jakarta, 27-28 Nopember 2007.

[4] Isjoni. (2010). Cooperative Learning. Bandung: Alfabeta.

[5] Turmudi, dkk. (2011). Strategi Pembelajaran Matematika Kontemporer. JICAUPI, Bandung. 